\title{
LABORS OF LOVE: On the Political Economies and Ethics of Bovine Politics in Himalayan India
}

\author{
RADHIKA GOVINDRAJAN \\ University of Washington \\ (iD) https:/ / orcid.org/0000-0002-4972-8663
}

"Maaaaaaaaaa," the audience, composed largely of women, repeats obediently after Kanha, the silver-haired guru (religious guide or instructor). Mother: what a cow is actually saying when uncomprehending humans think she is only mooing, he declares. Indu Joshi, ${ }^{1}$ a young woman with whom I am watching the gau-katha (a Hindu ritual event involving the performance of religious narratives about the cow) on Sanskar Channel in summer 2017, chants under her breath in unison with the ladies on the television screen. ${ }^{2}$ Her knees are tucked under her chin as she watches the screen intently during a short break from the laborious task of cleaning gobar (cow dung) out of the tin shed that houses the family's four cows who, at that moment, are at the grazing grounds with Indu's mother-in-law.

The gau-katha is taking place in the city of Haridwar, about two hundred miles from the village where we are, in India's central Himalayan state of Uttarakhand. Indu's tai (aunt, or more specifically, her husband's father's older brother's wife), who had once hosted the guru at her home in the nearby town of Almora, had called Indu a few minutes earlier and instructed her to watch the katha. Kanha, she said, was a fount of wisdom, and, more importantly, a true lover of cows. I knew him better as the head of a prominent right-wing cow-protection organization that wanted the Indian state to recognize the cow as Rashtra-Mata 
(Mother of the Nation) and institute the death penalty for anyone found guilty of slaughtering cows, thought of by cow-protectionists as an embodiment of the goddess Gau-Mata, or Cow Mother. Kanha was one of the most charismatic faces of a contemporary gau-raksha (cow-protection) movement, rooted in Hindu supremacist ideology, that has, over the past decade, authorized and enacted unremitting, sometimes fatal violence against Dalits (formerly known as "Untouchables"), Muslims, and other religious minorities identified as threats to the cow and a supposedly beleaguered Hindu nation that can only be united and secure under the maternal leadership of Gau-Mata (Gundimeda 2009; Contractor 2018; Govindrajan 2018; Imran 2018; Adcock and Govindrajan 2019).

"Listen," Kanha continues, his tone intimate and relaxed, "let me tell you mothers and sisters a story." He proceeds to describe how once-when the god Shiva was reciting a Rama katha (a religious narrative about the life of the god Rama) to his wife, Parvati - a parrot, eager to listen to the parable, arrived on the scene. Shiva felt enraged by the parrot's presence at the katha, the guru tells the crowd. "Now why would that be?" he muses. "Let the mothers assembled here ask Shankar (Shiva) what harm the parrot did by listening to this katha?" The camera turns on the audience, and I see women whispering to one another, wondering if anyone knows the answer. "Now that mother knows the answer," the guru says jubilantly, pointing at someone in the crowd.

"A parrot can only speak, but it does not work."

Suddenly, Kanha's joyful smile disappears. He shouts into the microphone, his hands chopping through the air for emphasis. "The problem with India," he screams, "is that too many parrots are born here today. They can only talk, they say Rama Rama, but they do not do the work of Rama." After leading the crowd in another forceful chant of "maaaaa," he takes a deep breath before coming to the denouement. "Take a vow to do Rama's work: protect and serve Gau-Mata (cowmother). Don't just say you love [prem] her, do the work [kaam] of loving her." The benevolent smile has returned to his face.

"What he's saying is true," Indu says, as she stands up to pull the television plug out of the electric panel. "Most people only talk of love. Just look at my father-in-law. He's always telling me that if I do this work [gesturing to the cow dung crusting on the edges of her saree and the tips of her fingers] with love, then I won't even know when the work is done. But when has he ever done the work of caring for animals? Talk of love [moh-maya] has force only when you break your back for it." 
At the time I thought Indu's comments were indicative of the anger she felt at her father-in-law's routine caustic commentary on how women of her generation tried to shirk work. It was only later that I realized her mediated "conversation" with the guru might illuminate something about a question that has long occupied anthropologists, political theorists, and philosophers: what constitutes the stuff of love? Much like anthropologists of love, neither Indu nor Kanha believed that love is a spontaneous eruption of intimate attachment between autonomous individuals (cf. Stout 2014; Kikon 2019). True love does not “just happen,” but entails work; its affective attachments have to be made flesh and blood through acts of labor. Declarations of love not substantiated through action are effete, merely parroted, as Kanha so contemptuously put it. Only a laboring subject could, they asserted, lay genuine claim to the status of a loving subject.

Beginning from this recognition of love as work, this essay asks how the specificity of the labors that organize and materialize affective attachments critically shape the nature and politics of love. More specifically, I explore how different kinds of situated labor produce varied kinds of love in the conjoined social worlds of right-wing gau-rakshaks and rural women dairy farmers in Uttarakhand. My interest in this question grew out of the realization that despite their agreement that love took work, the guru and Indu used different terms for attachments that one might gloss as love: prem and moh-maya. These terms, I argue, are not synonymous, but index distinct affective relationships imbricated in and emerging from distinct embodied regimes of labor. In what follows, I trace how prem, an idealized and desensualized love, emerged out of two highly visible forms of labor: first, the spectacular and well-publicized vigilante violence that young, male gau-rakshaks have unleashed on Muslims, Dalits, and Adivasis in the name of raksha (protection); and, second, the mediatized seva (service) performed by older gau-rakshaks, as well as ordinary urban women, an important part of which is producing audio and visual media for a Hindu audience united by their love for Gau-Mata. These highly visible forms of gau-rakshak labor and the prem that ensued from them stood in sharp contrast to the invisibilized labor and moh-maya of rural women. Moh-maya, a term that signals an illusory, even "deluded," form of loving attachment, was, I will demonstrate, attuned to a gendered arrangement of agrarian labor in which women were almost entirely responsible for the grueling and devalued care-labor involved in caring for livestock animals (Gold 2006).

Paying attention to the situated specificity of these relationships between love and labor, I argue, enables a renewed engagement with a larger question about the work that love, as a "political concept," does in the world (Hardt 2011; cf. Ber- 
lant 2011). ${ }^{3}$ The relationship between love and politics has long occupied scholars. While theorists like Michael Hardt $(2011,677)$ hold out hope that "a good love" might "create bonds that are at once" and multiply "intimate and social," others suggest that love is, at best, a politically ambiguous force. Love, the anthropologist Naisargi N. Dave (2016) thus asserts, is an "unjust ethic," because "when we love it is the one or ones who are special to us that we save." Elizabeth A. Povinelli (2005, 174) is similarly critical of love's politics, warning of the erasures of "enfleshed" bodies and worlds that "modern love" produces in its fetishization of the sovereign "subject-in-love."

These are important concerns that grow only more urgent in the face of the seemingly inexorable global rise of majoritarian political and religious movements thriving on what Nitzan Shoshan (2016) calls "the governance of affect" through discourses and practices that manage and mediate love and hate (cf. Johnson 2018). Indeed, "fascism as a politics of hate," as Sara Ahmed (2016) so astutely observes, "is written in a language of love." The centrality of love to fascist politics in the United States and the United Kingdom, she suggests, is revealed in how common it has become "for 'hate groups' to re-name themselves as organisations of love" (Ahmed 2003; cf. Ahmed 2004). "It is out of love," she writes (Ahmed 2003), "that the group seeks to defend the nation against others, whose presence then becomes defined as the origin of hate." In this essay, I elaborate on Ahmed's crucial insights on love and fascism to argue that it is not just the language of love but also the labor involved in loving that enlivens the politics of fascism. It is loving labor that endows fascism with meaning. The politics of the Hindu right-wing, I reveal, acquired force through the everyday work of protection and service performed by gau-rakshaks who sought to expunge "hateful others" not out of hate, but from irrepressible love (Ahmed 2003).

However, recognizing that love can involve varied labors reminds us that its political and ethical possibilities are multiple, and not necessarily exhausted by fascist authoritarianism. The penultimate part of this essay substantiates this claim by attending to how the quotidian care-labor performed by rural women who raise dairy cows engenders a love that thwarts the fascist purity of the prem that fueled gau-rakshaks. These women recognized that the moh-maya they felt for their cows was insufficient and impure because it was grounded in unequal distributions of power and value. Importantly, their ethical dilemmas and commitments were not shaped by an ethics of what Dave (2016) calls an "indifference to difference itself." They could not pretend indifference to their undeniable "complicity" (Thomas 2019a) in the violent extraction of animal labor. Indeed, they were often "haunted" 
(Govindrajan, forthcoming) by their willful participation in a system that drew its legitimacy from ideologies of intractable difference and hierarchy. Their acknowledgment of the violent limits of love, I argue, was shaped by an affective recognition of and reckoning with the capitalist, patriarchal regime within which feminized labor (both human and bovine) was devalued and naturalized. In the conclusion I suggest that it was precisely its lack of moral purity that imbued rural women's love for the cow with an ethical and political potential absent in gau-rakshaks' "pure" and irreproachable love for Gau-Mata.

\section{“JUST ONCE WORK FOR GAU-MATA WITH LOVE":}

\section{Cow-Protection, Religious Nationalism, and Sacred Geography}

Cow-protection constituted a critical node of a late nineteenth-century strain of Hindu nationalism that, as the anthropologist Peter van der Veer (1994, 2) argues, "fed upon religious identifications" and was "directly dependent on religious antagonism, between Hindus and Muslims.” In 1881, Dayanand Saraswati, the founder of the popular Hindu reform organization Arya Samaj, published a text called the Gaukarunanidhi, which made a strong case for protecting cows from slaughter (Adcock 2010). In the same year, his organization founded one of the first gaurakshini sabhas, or cow-protection assemblies, many more of which soon mushroomed across north India with the aim of preventing "cattle from 'passing under any circumstance into the hands of those who will either sacrifice them or slaughter them for food" (De 2019, 244). Members of these assemblies were often involved in coercion and violence against Muslims and Dalits, whom they suspected of slaughtering and skinning cows (Freitag 1980; Pandey 1986; De 2019). As historians have noted, this project of cow-protection, with its emphasis on the sacred inviolability of the cow's life, stood at odds with everyday rural economies in which cattle rearing, trade, slaughter, and consumption were inextricably intertwined (Chowdhury 1996; Adcock 2010; Kothiyal 2017). ${ }^{4}$

The association between cows, Hindus, and nationalism was strengthened by the emergence, in the same period, of the mother-goddess Gau-Mata (CowMother). Gau-Mata's iconic image — a white bejeweled cow, rounded body studded with Hindu deities — graced pamphlets and calendars distributed widely across northern India in the late nineteenth and early twentieth centuries (Gupta 2001; Pinney 2004). Gau-Mata came to stand as a symbol of Hindu (often collapsed with "Indian") community and nationhood alongside other maternal embodiments of "national territory," especially the goddess Bharat Mata, or India Mother (Ramaswamy 2010; cf. Gupta 2001; Pinney 2004). The guru's movement to have Gau- 
Mata constitutionally enshrined as Rashtra-Mata (Mother of the Nation) draws on precisely this century-old connection between the cow and the nation, even as it represents it as primordial.

In the years following 1947, the fact that "cows were not granted complete constitutional protection through a total, national ban on cow slaughter" even in an "independent Hindu dominant India" came to be framed by Hindu supremacist groups as a "historical injury" to Hindu sentiment and a sign of Hindu "impotency" (Chigateri 2011, 140). "Outrage" at this ongoing putative violence against Hindus continues to animate contemporary cow-protection politics (Jaffrelot 2008). The guru Kanha, for instance, frequently told his followers that they would remain "colonized" as long as their mother (the cow) continued to be treated as an animal and slaughtered. The very fact that even Hindus still called the cow an animal instead of mother, he thundered at gau-kathas and rallies, was a sign of how the Hindu spirit had been broken.

Importantly, right-wing religious figures like Kanha connect what they see as a broader history of injustice and violence against Hindus to more locally meaningful anxieties about identity and belonging, thus fueling the rise of what Joshi (2018) calls a "regional Hindutva." The project of cow-protection has put down deep roots in Uttarakhand, which now hosts hundreds of cow-protection organizations, precisely because it has been carefully interwoven into pahari (literally, of the mountain) politics. ${ }^{5}$ Fears about the erosion of a distinctive pahari cultural identity due to a lack of development in the mountains played an important part in fueling the mass mobilization for statehood that ultimately led to the creation of Uttarakhand as a separate Himalayan state in the Indian union in 2000, after it was carved out from its parent state of Uttar Pradesh. This invocation of a pahari culture at risk was linked to the distinct caste demography of the hills, which are majority upper-caste Hindu (Mawdsley 1999; cf. Mathur 2016; Koskimaki 2017). In 1994, the passing of state legislation reserving 27 percent of education and employment opportunities for Other Backward Classes (OBCs) in Uttar Pradesh, in addition to the existing 22.5 percent reservation for Scheduled Castes and Scheduled Tribes, led to widespread anxiety about further marginalization among upper-caste paharis if "half of all government jobs" in the hills went to a minority "lower-caste" population (Mawdsley, 1999, 104). As Emma Mawdsley (1999) observes, the widespread protests that erupted across the hills in response to this legislation breathed new life into what was then a waning popular movement for a separate state. 
However, as numerous scholars of the region have noted, the creation of a separate state has done little to assuage pahari anxieties in the face of a perceived lack of "development" diagnosed by widespread unemployment, industrial land grabs, agrarian crisis, and record rates of migration from the hills to the plains (Mathur 2016; Koskimaki 2017; Govindrajan 2018). It is these affective anxieties about access and belonging that the Hindu right-wing has managed to powerfully harness to the cause of cow-protection by repeatedly suggesting that the welfare of Uttarakhand's Hindus is intimately linked to that of Gau-Mata. This seemingly tenuous association is shored up through appeals to the widely shared belief that the Himalayan region constitutes a distinctly Hindu sacred geography, or a "living landscape in which mountains, rivers, forests . . . are elaborately linked" to the presence "and stories of the gods," and are gods themselves (Eck 2012, 4-5). Local pride in this sacred geography is reflected in the tag Devbhumi (land of gods) often used in popular and official discourse to describe Uttarakhand's status as home to several major Hindu pilgrimage sites. In recent years, the marketing of Devbhumi by the state and business investors has fueled the explosive rise of a dharmic (religious) industry - a network of gurus, ashrams, yoga and wellness retreats, and temples - that claims to draw its own potency from the shakti (creative power) of the Devbhumi (cf. Joshi 2018). Gurus who advocate the politics of cow-protection have flourished as part of this broader dharmic industry, adding their own ashrams and gau-shalas (cow-shelters) to the thousands of religious institutions mushrooming across the region.

The connections between the supremacist politics of gau-raksha and broader Hindu religiosity were brought home to me when I attended a nine-day bhagwat katha (a recitation of narratives from the Bhagwat Purana that has, increasingly, become an important ritual event across Uttarakhand) at a small village temple in the mountains. Gau-Mata featured prominently in the katha even though it was not a gau-katha. In one recitation, the vyas (the guru who recites the katha) attributed the emergence of the Krishna avatara to the gods' desire to protect Gau-Mata from rakshasas (demons) who sought to threaten her bodily integrity. After reminding attendees that the gods expected a good Hindu to do gau-seva (service for cows), gau-daan (gift cows), and gau-raksha, the vyas urged the crowd of mostly rural women to chant "Jai Gau-Mata" (Victory to Gau-Mata).

Religious figures like the guru Kanha often argued that paharis who were nourished by the Devbhumi were especially obligated to do gau-seva and gau-raksha. "Even the Ganga originates in Gaumukh (literally, cow face; the name of the Himalayan glacier from which the river Ganga originates)," Kanha told the audience 
forcefully during a gau-katha hosted by a locally significant temple in the mountains a few years ago. "There would be no Ganga without the cow, no Himalaya without the cow. There would be no Devbhumi without the cow. . . . You might have fought for this state, but take it in writing from me: you will not feel its benefits until you fight for Gau-Mata who is being cut mercilessly in the streets."

Abruptly, he flashed an amused, lopsided smile at the audience. "Don't sit at home and cry thinking about what will happen to your children and grandchildren," he chided, now gently. "Just once work for Gau-Mata with true love. Then see how quickly your children will succeed."

Kanha's diagnosis that the lack of development in Uttarakhand resulted from a lack of love for the maternal figure on whom the very existence of the Devbhumi depended seamlessly connected cow-protection, sacred geography, and development anxieties. As the next two sections detail, many gau-rakshaks echoed his emphasis on genuine love as an agent of political and social transformation, although the question of how to establish the authenticity and, thereby, the potency of this love remained open for debate.

\section{BETE KA PREM: Filial Love, Sacrifice, and Violence}

In 2017, I met two young gau-rakshaks, Monu Tamta and Vikas Nayal, at a coffee shop in the town of Haldwani. They had been introduced to me by an older gau-rakshak whom I had met at a protest called by the guru's organization in Haldwani a year earlier. After showing me several Facebook photos of themselves holding sticks and posing while patrolling state highways across Uttarakhand in search of cattle smugglers, they started to talk about prem, or love. Monu told me that he saw the work of raksha, or protection, as fueled by "filial love" (bete ka prem) for the cow. Vikas, who went to college with Monu, nodded his agreement and added that this was rashtriya-karya (work for the nation). When I pressed him to explain what he meant, he said, "the cow is the mother of the Hindu dharma. And this is a Hindu nation. ... Any Hindu who loves (prem) this country should be willing to lay down his life for Gau-Mata because she is not only our mother, but also the mother of this nation."

I was struck by the repeated use of the term prem, more formal than the colloquial pyar that young men like Monu and Vikas would usually use to describe their everyday affective attachments. Scholars have observed that while the original Sanskrit prema, love (from which the Hindi prem is derived), had a "wide and indeterminate connotation" in its numerous literary invocations, modern usages of prem in Hindi and other Indian languages often evoke an idealized and selfless 
love, shorn of sexual inference and imbued instead with a sense of ethical obligation (Kaviraj 2006, 164; cf. Ahearn 2001; Gold 2006). Some historians argue that this narrowing of prem's meaning dates to the late nineteenth century, when (Hindu) nationalist figures began to use it to index not just the idealized conjugal bond of the archetypal "Hindu-Aryan" nationalist couple but also a putatively pure and self-sacrificing love for the nation (Chakravarti 1990; Kaviraj 2006). It was precisely this modern history of narrowing in the "aesthetic," "conceptual," and sociopolitical meanings of prem that was reflected in Monu and Vikas's use of the term to signal the exalted nature of their love (Kaviraj 2006).

The affective force of this prem, Monu and Vikas told me, had forced them to "sacrifice" a launde ki normal life (the normal life of a carefree young man) in service of Gau-Mata and the nation. Later in the conversation, Monu fervently declared that it was because of the intensity of his prem that he was willing to "die and kill" for Gau-Mata and the country. When I asked what he meant, it was Vikas who responded, pushing his white, coffee-stained ceramic cup out of the way as he leaned across the table:

See, we do not justify the murders that have taken place. But there are some people who play with our emotions. That is what makes some Hindus react. That shows that their love is true [sacha]. This is why we are saying to the state, "respect our love, give our Gau-Mata her rightful place in this country." If the state doesn't act, then such attacks will continue.

The murders that Vikas was referring to were the recent mob lynchings of Muslim, Dalit, and Adivasi men, mostly in northern India, by vigilante gau-rakshaks, who, as Christophe Jaffrelot astutely observes, have formed a "parallel state structure" through which "the Hindu Rashtra (Nation) is materializing" (Anderson and Jaffrelot 2018). While Vikas carefully expressed condemnation of the lynchings, he was convinced that it was the failure of the state to enshrine Hindu emotion in law that compelled otherwise apolitical Hindus to violence (Jaffrelot 2008; cf. Adcock and Govindrajan 2019). Moved by love, they retaliated against those who, as Sara Ahmed $(2004,118)$ puts it, "caused injury" to the ordinary Hindu's "good feeling" of love. ${ }^{6}$

As far as Monu and Vikas were concerned, then, love committed them to the violent, masculine labor of purging those who hated the object of love. "It's not easy, this work," Monu confided when I met him again a few days later, this time without Vikas. "The nights we spend on patrol are exhausting. There's a real risk of 
death at the hands of cattle smugglers. ... But this is the nature of this work. You have to be ready to put in effort [mehnat]."

My conversation with Monu left me wondering what was at stake for him and other gau-rakshaks in claiming that the violence they unleash on religious and caste minorities constituted risky labor. It is worth noting here that the understanding of violence as sensuous, embodied, difficult labor resonates across multiple contexts (Hoffman 2011). Yet I would argue that there is something specific about the ways in which violence, love, and labor intertwined in the imaginary and praxis of gau-rakshaks. The labor of violence was what imbued their love for the cow with affective force and meaning. Rakesh Tewari, a recent college graduate and member of a Haldwani-based cow-protection organization, expressed this sentiment when he told me that his prem for Gau-Mata had "real josh" [fervor, force] because he was "fearless" and "willing to do whatever was needed" to protect her. What young men like Rakesh, Monu, and Vikas were suggesting, then, was not simply that love moved them to action. Instead, they insisted, it was precisely their willingness to engage in risky, violent labor that revealed the depth of their love for the cow, that made their love sincere and authentic.

Establishing the authenticity of their prem was a remarkably important concern for all the gau-rakshaks I knew. However, what made love for Gau-Mata genuine was a matter of some debate. Younger men like Vikas, Rakesh, and Monu claimed that the purity and sincerity of their love manifested through their participation in acts of violence. As a result, they often criticized those male gau-rakshaks who refused to go out on patrols and preferred to run gau-shalas (cow-shelters) instead. "Anyone can run a gau-shala," Dikesh Pandey, a gau-rakshak I spoke with in 2016, said to me disparagingly when I asked if his involvement with local gaushalas extended beyond dropping off the cows he rescued. "But what we do-raksha - is the real work. It's risky."

If younger gau-rakshaks privileged a risk-taking, violent, masculine subject as the authentic lover, older men involved in gau-raksha tended to emphasize seva (organized service) as the basis of genuine love for the cow and the nation. The selfless work of seva, they argued, engendered an entirely different relationship between love and labor than the work of masculine violence, which they construed as glamorous and self-serving. As I demonstrate below, the ideal of seva allowed older gau-rakshaks to both counter the critical narratives of younger gau-rakshaks and legitimize and conceal the communal violence of gau-raksha. 


\section{THE COW WHO WENT TO A KATHA: Altruism, Mediation, and}

\section{Gender in Gau-Seva}

The afternoon sun was beating down without mercy by the time I arrived at the modest gau-shala located in a peri-urban area near Haldwani a few years ago. I had been directed there by Uma mausi (mother's sister), the sister of a woman with whom I had lived briefly during dissertation fieldwork in 2010. Uma mausi had waxed eloquent about Mohan Chand Pandey, the man who ran the gau-shala. "He's donated his own land to the gau-shala," she gushed. "Such an unselfish man."

Pandey greeted me with a rousing "Jai Gau-Mata Ki!" (Victory to Gau-Mata). When we sat down on a stone platform in his courtyard, he started recounting his life history. Gau-Mata had visited him in a dream six years ago, he recalled, and had told him that his life would be fulfilled if he opened a gau-shala and did seva for sick and elderly cows and abandoned bulls.

When I inquired as to what the quotidian doings of gau-seva (cow-service) involved, Pandey enthusiastically began to describe an ordinary day at the gau-shala.

When I wake up, I first pray to a cow, here in the gau-shala. After bathing, I start sending people good morning messages. Thousands of people receive my messages daily. People nowadays send roses and other random [unt-shunt] things like that. I send only pictures of Gau-Mata. Sometimes I share video clips from gau-kathas. Sometimes I make videos of the gau-shala and send those. I send things that touch the heart, that awaken [jagruk] the spirit. Like this morning, I sent a picture of a cow who goes to a temple daily to listen to a katha. Bhai [brother], a cow is going to a katha, and you're sitting at home watching serials on TV? Think about that for a minute.

As Pandey described other images he had shared recently, I was struck by how little time he actually spent with the cows at the shelter. In addition to his early morning visit, he usually went to the gau-shala (attached to his house) a few times a day. His visits were motivated by a desire to "supervise" the workers responsible for feeding the cows (with grass bought locally from women farmers and commercial livestock feed) and collecting their urine and dung (both of which were sold to local and national distributors). Many of the workers, particularly those who collected urine and dung, were local women who kept animals of their own.

The bulk of Pandey's own seva, then, entailed hours of painstaking labor to produce and disseminate what Shakuntala Banaji $(2018,3$, 7) calls "Hindutva 


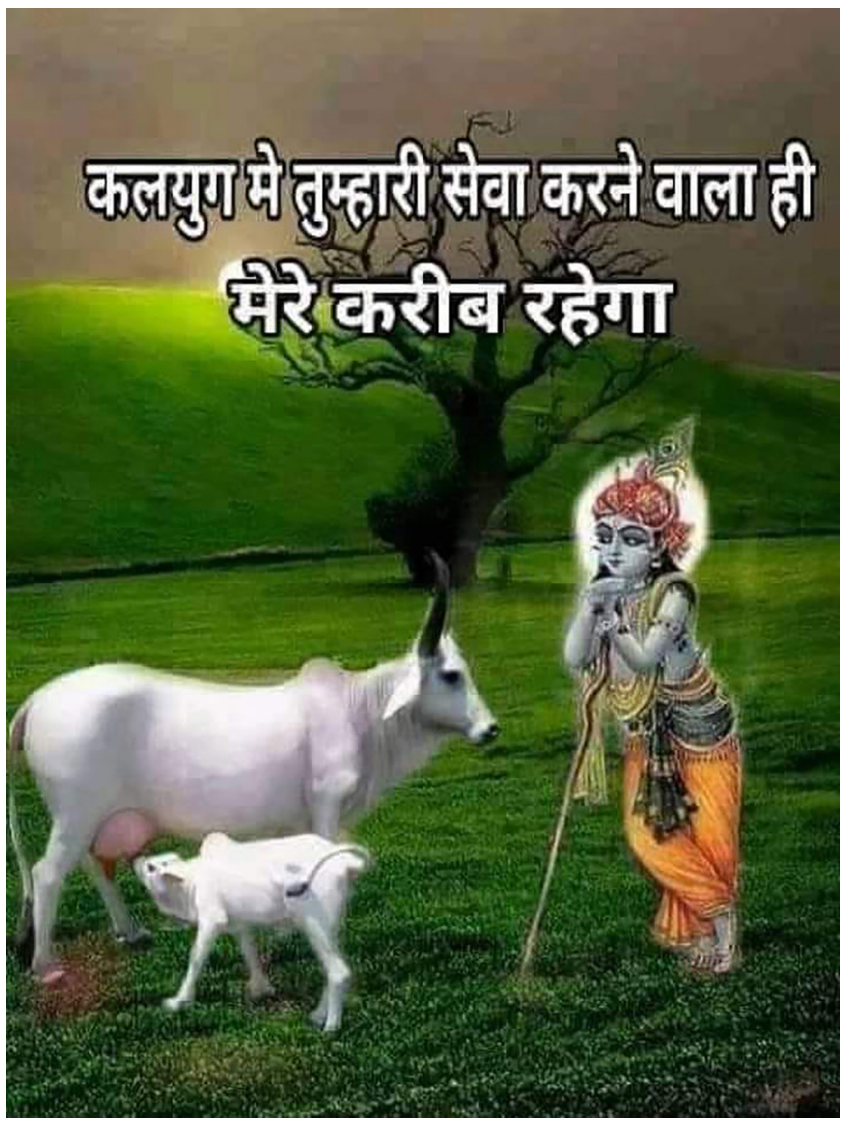

Figure 1. An example of the images extolling gau-seva that circulate over social media. Photo credit: Gau Mata Gau Seva Trust. https://www.facebook.com/savecowsaveindia/ photos/a.1601791173430734/2577371205872721/?type=3.

media productions": digital media, especially audio, images, and video, that have played a vitally important role in producing a "new Hindu majoritarian 'national subject" from the 1980s onward. As Sahana Udupa (2018, 453) notes, this "mediatized form of Hindu nationalism" increasingly thrives on the "entrepreneurial" work of a wide range of social actors like Pandey (cf. Mukherjee 2020). Like other "online volunteers of Hindutva," Pandey understood this mediated seva as intrinsically driven by an altruistic desire to awaken Hindu sentiment and cultivate an affective community of Hindus united by the force of their emotion for Gau-Mata (Udupa 2018, 456).

Pandey insisted that it was only through such spontaneous and public-spirited seva that one could experience genuine love and devotion for Gau-Mata and the Hindu nation. As such, he pointedly distinguished his work from that of vigi- 
lante gau-rakshaks who, as he contemptuously, and even a little defensively, put it, "went around believing that nobody was as good as them just because they had beaten up some cattle smugglers." "Anybody can beat up people in the name of the cow," he said disapprovingly. "But just mention gau-seva and watch how fast they run." Their violence, he concluded, resulted from a desire to publicly display (dikhava) their masculinity (mardangi). It had nothing to do with the feeling (bhava) of true love or devotion for Gau-Mata.

Ultimately, for Pandey, the work of young vigilantes proved insincere because it was imbricated in "dirty politics" and, therefore, hypervisible in national political discourse. "No newspaper or television channel will tell you about the seva that gau-sevaks like us do. But let there be a hint of a scuffle on the highway, all these media people will immediately arrive with their cameras. These boys [referring to gau-rakshaks] know what the public, the media is hungry for. It's all politics."

Seva, on the other hand, aroused and was fueled by authentic feeling because it had nothing to do with politics. "Seva means working without any selfish intent, without any politics, without any desire for fame. You do seva because of the feeling in your heart," he declared. He warned me not to take seva lightly. It was, he said, the only thing that stood between Hindus and their destruction as a people. "Do gau-seva and you will have saved the Hindu family, Hindu society, and Hindu nation. Otherwise, there will be nothing left."

While the political ideal and practice of seva, which lays "emphasis on principles of selflessness and sacrifice," has been central to a range of nationalist projects for well over a century, it has played a particularly important role in buttressing right-wing Hindu constructions of the self, community, and nation (Ciotti 2012; cf. Kaur 2005; Patel 2010; Thachil 2014). Indeed, the connection that Pandey sketched between gau-seva and the reinvigoration of the Hindu family, society, and nation is emblematic of the ways in which Hindu supremacists mobilize the seemingly apolitical discourse of seva as part of their violent nation-building projects.

The stress on the selfless and sacrificial aspects of seva was important, however, because it allowed Pandey to distance himself from the politics of street confrontation practiced by vigilante gau-rakshaks. By emphasizing seva as the basis of love for the nation, materialized in the body of the cow, gau-sevaks like Pandey and gurus like Kanha managed to attract broader audiences, particularly women who have historically been drawn into Hindu nationalist mobilization through the ideology that altruistic seva for the nation should cut across caste, class, and gender (Dyahadroy 2009; Ciotti 2012). While the ethos of seva, with its emphasis 
on self-renunciation and discipline as a path to resurrecting the "essential Hindu nationalist self . . . and ideal Hindu nation," is fundamentally masculinist, it still offers women an opportunity to cultivate an independent "feminine self" through daily service for ideals and entities beyond the husband and family (Bacchetta 1993, 40). Certainly, over the past decade, older pahari women from across castes and unaffiliated with any Hindu supremacist organization have become regular attendees at gau-kathas because they provide a space from which to participate in nation-making through bhakti (devotion) and seva. The preponderance of women in the audience at any gau-katha reveals how the understanding of cow-protection as a masculinist enterprise rooted solely in vigilante violence (cf. Mukherjee 2020) fails to capture the ways in which cow-protectionists appeal to broader social worlds by casting the work of cow-protection as mediated, apolitical seva, open to anyone willing to sacrifice self-interest for a larger cause.

In fact, Uma mausi had insisted that I meet with Pandey precisely because he was a sevak, not a gunda (goon), a term she used for some of the younger gau-rakshaks with whom she knew I had been meeting. "There's not a trace of violence in that man," she announced when I met her at her house in Nainital a few days after my conversation with Pandey. "He sends such wonderful WhatsApp [messages], only pictures of devis [goddesses], devtas [gods], and cows." She beckoned me to sit beside her on the chintz-covered sofa, so that I could look at the images closely on her phone. "He has inspired me to do some seva myself." When I asked about her seva, she told me that she not only spent hours every day forwarding WhatsApp messages about the cow to friends and family members but had also convinced several of them to donate money for food and medicine to gau-shalas. "Initially I had told Pandey ji that I couldn't help him because I don't like traveling," she said. "But he told me that all the gurus agree that any work done with love [prem] and devotion [bhakti] is seva. 'You can sit at home and send WhatsApp', he told me, 'don't think of that as lesser work."'

Uma mausi's account of how she became involved in gau-seva reveals that it is not just the ideology of seva, but a capacious sense of what seva could entail that draws many women into the cow-protection movement. For instance, Chetna Ram, a young woman who attended college in the town of Almora, shared with me that she would drop a few coins in the plastic donation jar, shaped like a cow with full udders, that lived on the counter of her favorite clothing store every time she shopped for new jeans or blouses.

"Bhaiyya [the shopkeeper] once told me that several gau-shalas are able to buy grass for cows only because of donations from Almora bazaar," she recalled. 

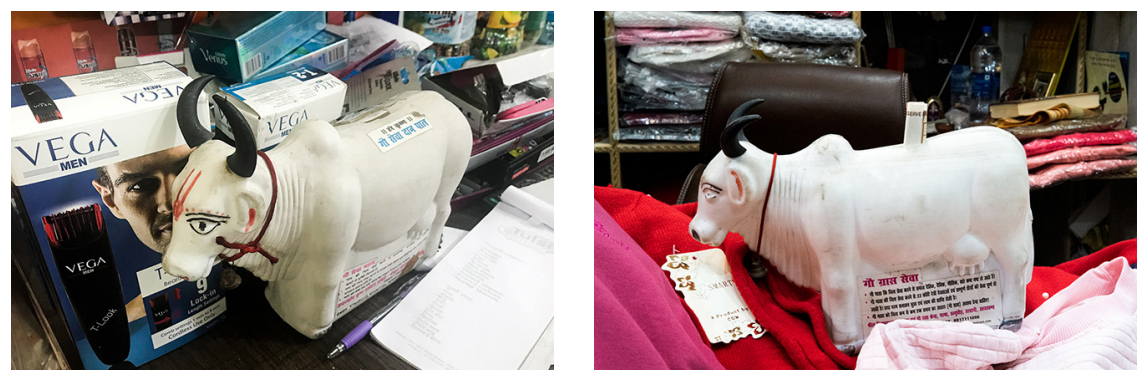

Figure 2 and Figure 3. "Cow banks" requesting donations to buy food for cows. Photos by Radhika Govindrajan.

The idea that one could work toward cow-protection through acts as quotidian as pressing forward on a devotional WhatsApp message or dropping spare change in a donation jar clearly allowed individuals like Uma mausi and Chetna, who were loosely (if at all) connected to formal cow-protection organizations, to feel as if they were playing their own small part in constructing the Hindu nation.

And yet this understanding of seva was also the source of deep misgivings for many rural women who felt that such a broad conception of service as labor devalued their own grueling and invisibilized agrarian labor. Rekha Kandpal, Uma mausi's sister, was a passionate exponent of this view, as I was to find out when I visited her a few days after my trip to Nainital. Having pressed me for the fine details of my conversation with Pandey and her sister, Rekha chachi [aunt, more specifically, father's brother's wife] appeared indignant when I told her how Uma mausi had become a gau-sevak. "What are you saying re?" she sputtered. Her daughter-in-law, who had just come into the room, asked what the fuss was about. "Uma mausi thinks sending WhatsApp is doing work for a cow," Rekha chachi said, her voice dripping with scorn. "And look at us fools, spending all our days cleaning cow-dung and taking our cows out to graze."

Though somewhat mean-spirited, Rekha's refusal to accept Uma mausi's seva as a legitimate form of labor illuminates the limits of the politics of cow-protection, particularly among rural women. Over the course of my fieldwork, I found women farmers were often deeply critical of the ways in which gau-rakshaks understood the meaning of labor and love. Ironically, they usually articulated these critiques during the course of the gau-katha itself, whether they were attending in person or watching on television. These critiques did not mean that these women rejected gau-kathas in their entirety. On the contrary, gau-kathas were becoming increasingly popular among rural women for a variety of reasons including the fact that attendance at kathas of all kinds was increasingly a source of social prestige. Many 
women who attended gau-kathas felt genuinely conflicted about what it meant to live ethically in relation to the cows they raised and hoped that gurus might offer some answers. And yet, they often found the gau-rakshak ethical imaginary wanting on the grounds that it failed to understand the ethically fraught nature of their everyday relationships with cows. As we shall see in the next section, these ethical dilemmas, and the conflicts they engendered, were at their most acute in debates about cow milk and about how to understand the feminized labor of cows.

\section{A HOLIDAY FOR GOPULI: Milk, Feminized Labor, and}

\section{Unequal Solidarities}

While male gau-rakshaks, young and old, regarded their love for Gau-Mata as genuine because they labored for her (whether through violence or seva), they believed that Gau-Mata's mamta (maternal affect) for her children expressed the spontaneous and innocent love of a primordial mother. The naturalization of the cow's maternal role was most forcefully expressed in gau-rakshak claims that the cow's maternal "gift" (ma ki bhent) of milk formed the substance of the kinship between Gau-Mata and her children. As the historian Charu Gupta (2001, 4296) notes, the idea that the cow was a "universal mother . . . reached deeply into the Hindu psyche" in the late nineteenth and early twentieth centuries. The widespread circulation of images and texts that depicted the cow nourishing bovine and human (Hindu) children with her milk lent affective weight to claims that the "well-being of the Hindu nation" depended on the consumption of cow milk and ghee (Gupta 2001; Gould 2004).

Contemporary gau-rakshaks continue to emphasize the importance of cow milk in substantiating kinship with Gau-Mata, often referring to their labors as motivated by the desire to pay off the "debt" of the cow's "gift" of milk (cf. Narayanan 2019). Such claims about the cow's innocence and generosity, and the reciprocal obligations they imposed on her children, were repeated by multiple actors at a rally organized by the guru Kanha's organization in Delhi a few years ago.

In the middle of the day, one of the volunteers for the organization, a woman from the city of Haldwani, stopped by to talk to the contingent of rural women from the mountains with whom I was sitting. She commanded us to commit ourselves to gau-raksha as she handed out small yellow paper flags bearing the iconic image of a cow with several Hindu deities embedded in her body. Our commitment was necessary, she said, because Gau-Mata was too innocent (masoom) to protect herself. All Gau-Mata cared about, she said before walking away, was caring for her children, which was why she "always had milk in her udders" to feed them. 

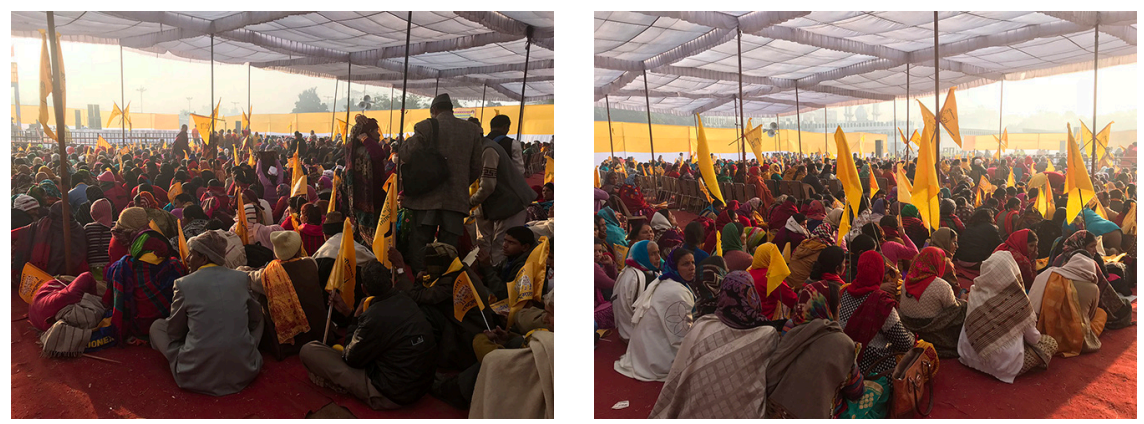

Figure 4 and Figure 5. The crowd at a cow-protection rally called by the guru Kanha's organization. Photos by Radhika Govindrajan.

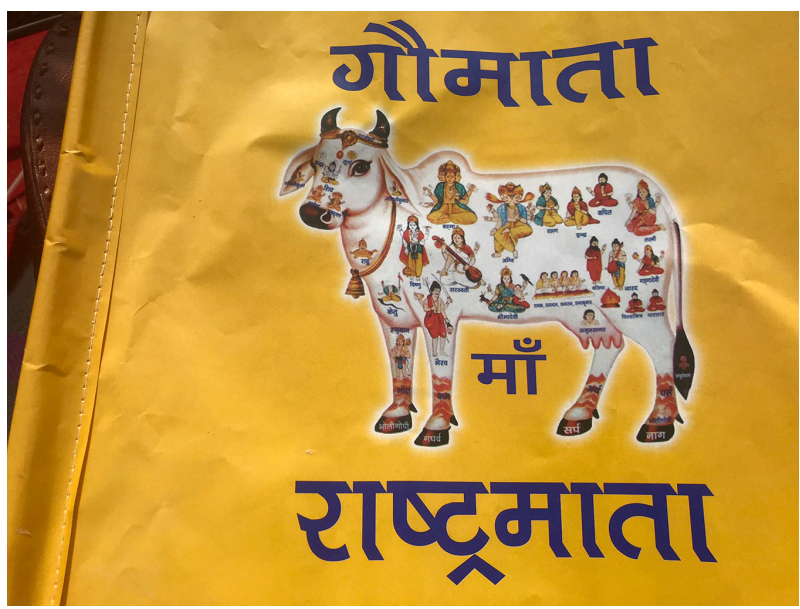

Figure 6. A yellow paper flag with an image of a cow with Hindu deities in her body and text that reads “Gau-Mata Rashtra-Mata.” Photo by Radhika Govindrajan.

Another gau-rakshak, a young man from Dehradun who started a conversation with me as we stood in the long line for tea during a break between speeches, described how he had come to gau-raksha because of his gratitude for the cow's mamta (maternal affect). As we parted ways, he told me that he did not care about politics and was not affiliated with any political party. He did this work, he said, because he "loved Gau-Mata from the heart," and because her "innocent face" haunted him. He was here, he continued, because Gau-Mata needed her sons; she was too "innocent" to fight the "cunning butchers" (we both knew without him needing to clarify that he was referring to Muslims) who thirsted for her blood.

I was struck by these claims that gau-raksha was driven purely by the imperative to protect the cow's maternal innocence. Miriam Ticktin's (2017) work on the politics of innocence is useful in understanding how innocence comes to be such a 
powerful force in driving political action. Ticktin $(2017,578)$ notes that the "ethico-moral" concept of innocence "promises a space of moral and epistemic purity" in which the deserving are easily separated from the undeserving. In the narrative discourses of gau-raksha, the innocence of Gau-Mata holds out the promise of a purified Hindu nation in which only the cow and her Hindu children are "worthy victims" (Ticktin 2017, 577). It is the cow's innocence and purity that enables the identification of the "cunning butcher" as unworthy of membership in the nation. It is the innocent face of Gau-Mata that allows the young gau-rakshak from Dehradun to distance himself from politics and absolve himself of responsibility for the (often fatal) violence that young men like him visit on the "uninnocent" in the name of love.

Apart from serving to displace religious and caste minorities to the limits of humanity, gau-rakshaks' narratives of innocence also naturalize the cow's milk-producing labor by casting the cow as an idealized maternal figure whose natural instinct to nurture any child (whether human or nonhuman) is so strong that she is incapable of withholding milk from them. As Yamini Narayanan $(2019,201)$ argues, "the celebration . . . of the lactating cow as a freely giving, sacrificing mother . . . illuminates the instrumentalization of bovine motherhood and breastmilk to serve Hindu patriarchy." The image of the cow as a natural mother, whose udders are always overflowing with milk for her children, erases the fundamental violence of dairy production, whereby cows are routinely (and forcibly) impregnated for milk that is then "diverted" from their calves (Gillespie 2018; Narayanan 2019).

Indeed, it was precisely at such patriarchal representation of feminized labor as "natural" and "spontaneous" that rural women across castes directed their sharpest critiques. Almost all the pahari women farmers I spoke with at gau-kathas and rallies expressed a deep dissatisfaction with how the discourses of purity and innocence naturalized, and thereby erased, feminized labor, both their own and that of their cows. For them, such discourses evoked and reinforced a broader patriarchal devaluation of the "back-breaking" farm labor that women performed to keep mountain agrarian economies afloat (Gururani 2010; Govindrajan 2018). In the rural mountain region where I have conducted fieldwork for more than a decade now, women were primarily responsible for and spent their entire day doing the arduous work associated with cultivation, fodder and fuel collection, and care of livestock animals, in addition to their quotidian (and also burdensome) household labor. Men often dismissed this labor as "women's work” (saini kaam), with many commenting that women "chose" to overwork themselves as part of 
their innate feminine nature or because they were maddened by the "petty" desire to show off how hard they could work to their peers.
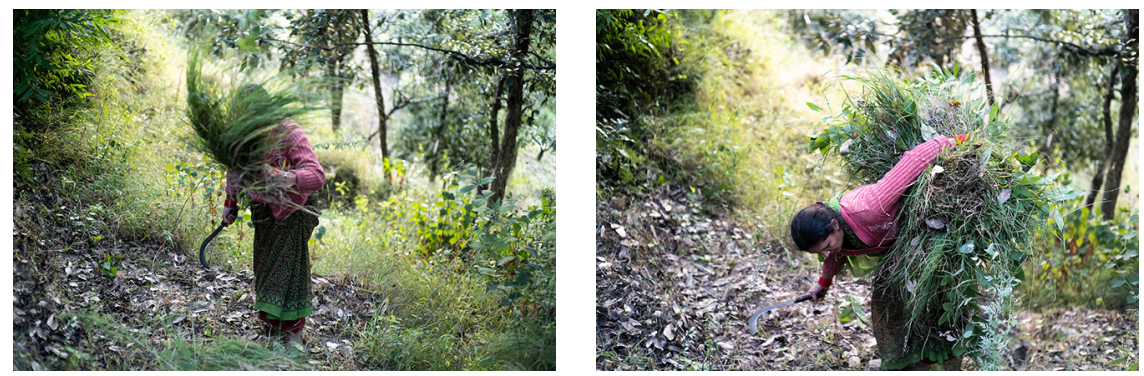

Figure 7 and Figure 8. The grueling labor involved in raising livestock falls entirely upon women. Photos by Radhika Govindrajan.

Women countered this devaluation of their work by pointing to the ways in which it was crucial to keeping mountain social worlds afloat in times of distress. In particular, they stressed how the grueling labor they performed in caring for dairy cows created a precious, albeit small and precarious, stream of income from the sale of milk to the many state- and privately owned dairies that have mushroomed across the mountains as part of rural development schemes during the past two decades (Govindrajan 2018).

Importantly, they recognized that the labor involved in this economy was not just human but also nonhuman, specifically bovine. In other words, they recognized that the devaluation of gendered labor cut across species. Thus, for example, the women with whom I had attended the cow-protection rally were skeptical, to put it mildly, of the volunteer's claim that a cow naturally had milk in her udders for her children. After the volunteer had walked on to greet another group, a woman from the mountains sitting behind me snorted derisively and asked the others if they thought this woman had ever milked a cow in her life. "Which cow gives milk just like that?" she asked, a tone of disbelief in her voice. One of the other women in our group responded that the volunteer was clearly a woman from the city who didn't understand the nature of farm labor; she didn't even know that there would be no milk without the labor of women and cows.

I heard a similar sentiment from Hema Joshi, a woman from a mountain village who was locally renowned for being "mad" about her five Jersey cows. "Yeh saara karobar inhi gayon ka to hai" (this whole business belongs to these cows), she said to me when I met her at the grazing grounds in her village in the winter of 2019. The business she spoke of was the ten thousand rupees she earned every 
month after selling milk to a private dairy that belonged to a local artisanal cheesemaker. "Without their mehnat [effort, labor], I wouldn't have anything to send to the dairy. Their mehnat is what keeps me afloat." Her use of the words karobar and mehnat was significant, highlighting the imbrication of bovine labor and milk in commodity exchange and thereby calling into question the claim that cow's milk was the freely given gift of a loving mother.

While such assertions certainly challenged the gau-rakshaks' imaginary of cows as natural mothers, one might argue that they ran the risk of representing cows as natural workers, voluntarily integrated into capitalist systems of dairy production (Besky and Blanchette 2018; Paxson 2018). Maan Barua's (2018) important caution that "animals . . . are not self-directed creatures exchanging alienable labor in the marketplace of their own volition" is pertinent to recall here. Yet rural women resisted the urge to "naturalize work" in two important ways: first, by actively criticizing the ways in which feminized labor, both human and nonhuman, was naturalized and, thereby, invisibilized; and second, by acknowledging (and being unsettled by) the violence that they themselves inflicted on cows' bodies. Below, I offer two ethnographic moments to illuminate how such critiques emerged in the course of everyday life.

The conversation as we huddled around the hearth on a winter evening in 2017 had turned from completing preparations for that night's puja to cows. Bhaga Arya, who had only just returned from the shed after milking the cows for the evening, was telling her mother-in-law that Gopuli, one of the cows, had refused to give milk for the fourth day running. "There's a new pashu ahaar [livestock feed] in the market. Perhaps we should buy that for her." Her mother-in-law agreed that this was a good idea, and told her son, who was sitting in the next room, to buy the pashu ahaar when he went to work the next day. "There's another thing we can do," Bhaga said, extending her toes towards the hearth. "In my mait [natal home], we would let the cows rest for at least a year and a half or two after giving birth before we took them to the bull again. Let Gopuli rest and build her strength. She is still young." Her mother-in-law, nodding off from the heat of the fire, opened her eyes momentarily to acknowledge that this was worth thinking about. It was at that moment that Bhaga's father-in-law, who was sitting in the next room with her husband and listening to our conversation, decided to intervene. "What nonsense," he sneered. "Cows don't need to rest. They are meant to have children. Why else do we call the cow Gau-Mata? Lazy women will tell any lie to get out of work." 
Bhaga's face was etched with hurt and anger. A few minutes later, she stood up and asked if I wanted to accompany her to the bathroom. She exploded the moment we stepped out into the courtyard, declaring that men in the mountains expected women and cows to spend their whole lives giving birth to children and laboring, as if that is all they were born to do. "Forget me, he [referring to her father-in-law] won't even let the cows live their lives in peace," she said, finally, before turning to head back into the house.

I was struck by Bhaga's assertion that patriarchy affected the possibilities of life for both humans and nonhumans. Her words illuminated how women and cows were subject to (re)productive control within a capitalist, patriarchal system that represented their labor as an expression of natural feminine desire or, as Sylvia Federici (1975) so powerfully put it, an act of "love" (cf. Bear et al. 2015; Jegathesan 2019). The connection she felt with Gopuli was thus rooted in this shared experience of the erasure of their unnatural and unpaid labors. However, even as women like Bhaga claimed a certain kinship with cows on these grounds, they were also painfully aware of the coercive power they wielded over their bovine companions. One day in 2018, when I was at the grazing grounds in the village of Pokhri, Mohini Nayal, a neighbor of the family I was living with at the time and a devoted viewer of televised gau-kathas, started to tell me how she had recently lined the walls of her cowshed with old shawls so that the cows wouldn't catch a chill. One of the women who had joined our little circle commented on how much Mohini chachi loved her cows. The word she used was moh-maya (literally, the illusion of love), which pahari women often used to index the affective bonds of love (cf. Govindrajan 2018).

Mohini chachi's response was remarkable for the ways in which it recognized both the love she felt for her cows and the limitations of that love:

What a thing God has made, this love. After a lifetime of doing work for animals [jaanwaron ka kaam] you come to feel such moh-maya for them that you can't sleep at night thinking of them trembling in the cold. But in the end, we sell or let them loose after they stop giving milk. . . This greed for milk is a terrible thing. I don't know if God will forgive us for thieving milk from their calves. . . Maybe that's why we call it moh-maya.

Mohini chachi's use of the terms moh-maya and maya-mamta instead of prem, or even the more colloquial pyar, proves significant because maya evokes both a sense of illusion and of "attachment, affection, compassion, and love" (Lamb 2000). Indeed, 
moh-maya, as Ann Grodzins Gold (2006, 306) notes, often carries implications of delusion. This semantic openness was precisely what Mohini chachi was wrestling with as she reflected on the intensity of the affective bond she shared with her cows as well as its ethical limits. It was the embodied, intersubjective labor involved in raising cows that created her "thickly enfleshed" attachments to them, attachments she understood as moh or love (Povinelli 2005; cf. Jalais 2009; Govindrajan 2018).

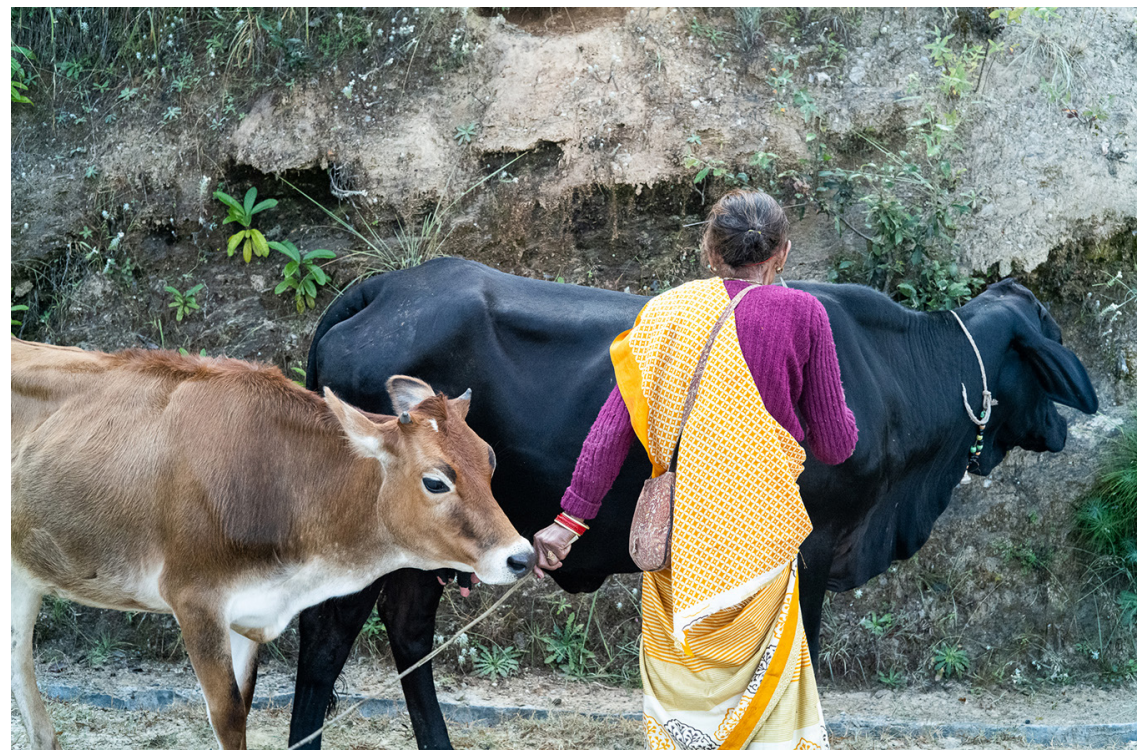

Figure 9. Embodied, intersubjective labor is the basis of moh-maya. Photo by Radhika Govindrajan.

What made this moh often seem like maya was precisely the fact that it was subject to the impure and power-laden transactions of everyday life in capitalist rural economies. For it was because they themselves were subject (though unequally) to patriarchal regimes of feminized labor that Mohini chachi and others like her were keenly aware that a pure and innocent love for the cows they engaged in unnatural labor could only remain illusory if not delusional.

\section{CONCLUSION}

What might these varying conceptions of love and the labor it entails illuminate about the political regimes that love (and its affine, hate) makes possible? Is love doomed to what Michael Hardt (2011) describes as narcissism, or can it 
seed the ground for an ethics of an incomplete but ongoing accountability to those other than the self? The question of love's politics is particularly crucial in this moment when violent love has become the dominant affective register for authoritarian and fascist politics worldwide. Thinking about love as work, I have argued, allows us to apprehend how it can, depending on the specificity of the labor involved in its realization, both fuel and exceed fascist politics. To put it differently, attending to the varied labors of love in situated social worlds reveals how love can condition a variety of often conflicting political and ethical possibilities, working simultaneously as a force of "transcendence" (Dave 2016), "self-sovereignty" (Povinelli 2005), violence, and "repair" (Thomas 2019a). A reparative love, I propose, refuses purity and coherence, and instead works through complicity and ambiguity. It demands ongoing embodied labor that is relational, "response-able," and aspires to transformation even as it remains mired in violence (Thomas 2019a). Following Deborah A. Thomas (2019b), I understand loving repair as "a daily practice of recognition and love" that "destabilizes the boundaries between self and other, knowing and feeling, complicity and accountability" (emphasis mine). Reparative love is thus work-in-progress.

Let me illustrate what I mean by returning briefly to the loving labors performed by gau-rakshaks and rural women. Vigilante gau-rakshaks believed that the sincerity of their love for the cow was reflected in the violent labor they undertook to expel those who hated Gau-Mata from an otherwise love-filled Hindu nation. While older gau-rakshaks preferred the labor of mediated seva to vigilante violence, they, too, understood their work as a form of inherently masculine labor directed toward securing the nation (inseparable from Gau-Mata) from those incapable of truly loving it. True prem, in both these cases, was understood as transcendental, unmoored from the constraints of an "enfleshed" world and directed toward an abstract object of devotion (Povinelli 2005). It was also beyond doubt or reproach in a way that did not allow for any reflection on the extreme inequality, exclusion, and violence that buttressed it. This prem was not, as I have demonstrated, the love to which most rural women were attuned. Indeed, the women who labored on and for cows recognized that a pure and transcendental love was fundamentally delusional given their incontrovertible collusion in the violent extraction of bovine labor characteristic of capitalist dairy economies. Yet this did not stop them from laboring, in largely unseen and invisibilized ways, toward a more ethical and just love within the "contaminated" reality they inhabited (Ticktin 2017, 588). Their tentative ethical strivings, shorn of the assurance with which gau-rakshaks pursue their love, bring to mind Ticktin's $(2017,588)$ powerful assertion that a "world 
without purity ... [where there is] no place of moral transcendence" might well be "the site of new political emergence."

Indeed, my final conversation with Bhaga provided a powerful reminder of the possibilities for solidarity and reparative justice that an undeniably impure and yet ever-striving love might hold. In September 2019, while on a visit to her home, I asked what had come of her attempts to convince her mother-in-law that Gopuli could do with a "rest" between visits to the village bull. She told me that while her efforts had failed the first time, she had since taken a different direction and worked on her husband to join her campaign. When I asked about the outcome, she laughed and said that Gopuli was finally enjoying a much-deserved chhutti (holiday).

\begin{abstract}
This essay asks how conceptualizing love as work might provide a fresh perspective on love's politics. In offering an ethnographic account of how love for Gau-Mata, the Cow-Mother of the idealized Hindu nation, fuels a right-wing Hindu nationalist politics of cow-protection in India's central Himalayan state of Uttarakhand, I suggest that the specific arrangements of labor through which affective attachments are organized critically shape the ethics and politics of love. More specifically, I depict how different kinds of situated labor produced varied kinds of love in the conjoined social worlds of right-wing gau-rakshaks (cow-protectionists) and rural women dairy farmers in Uttarakhand. For these social actors, genuine love for the cow manifested in a willingness to labor for her. Yet their understandings of what this loving labor entailed differed starkly. This article examines three distinct kinds of work-protection, service, and care-labor - that these actors variously undertook out of love for the cow. It traces how these different labors produced a varied set of relationships, affiliations, and obligations that crucially shaped the ethics and politics of love. Ultimately, I show, attending to the varied labors of love in situated social worlds reveals how love can condition a variety of often conflicting political and ethical possibilities, working simultaneously as a force of transcendence, fascist violence, and repair. [love; fascism; gender; affect; labor; cow protection; Hindu nationalism; South Asia; Himalaya]
\end{abstract}

\title{
NOTES
}

Acknowledgments This article is based on conversations and encounters with numerous people in Uttarakhand to whom I am grateful for their time. I owe a particular debt of gratitude to the many rural women who have drawn me into their lives with unmatched warmth and generosity over the past decade. I am thankful to the four anonymous reviewers whose incisive and perceptive comments have improved this essay immeasurably. I would also like to thank the editors, especially Brad Weiss, for their thoughtful and generous suggestions for revision. Various drafts of this essay have benefited from the insights of Kemi Adayemi, Mona Bhan, Maneesha Deckha, Jean Dennison, Ishita Banerjee Dube, María Elena García, Jenna 
Grant, Sunila Kale, Christian Novetzke, Juno Parreñas, Priti Ramamurthy, Gabriel Rosenberg, Harris Solomon, Sher Ali Tareen, Anand Vaidya, and many others. Versions of this essay were presented in talks at several institutions. I am grateful to those in the audience for their questions and comments, all of which have shaped this essay in critical ways. Research and writing for this piece were made possible through generous support from a Simpson Center Society of Scholars Fellowship, a Royalty Research Fund Fellowship, and an American Council of Learned Societies Fellowship. Finally, thanks to Jessica Lockrem and Petra Dreiser for their helpful editorial assistance.

1. To protect people's identities, all names used in this essay are pseudonyms.

2. Kathas are "religious stories, whose performances constitute a demarcated ritual event" (Narayan 1992, 46). As Kirin Narayan $(1992,46)$ notes, "The narratives told are from the epics, the Puranas, and regional religious traditions." Gau-kathas follow the generic katha format but focus on stories that emphasize the central place of the cow in Hindu dharma (religion). Gau-kathas have become increasingly popular during the past decade. In addition to drawing in-person audiences in the thousands, they also occupy primetime slots on Hindu devotional television channels like Aastha and Sanskar.

3. I am grateful to Naisargi Dave for having encouraged me to think through this question in the context of my ethnographic work.

4. Cassie Adcock and I (Adcock and Govindrajan 2019) argue that the oft-repeated claim that cow-protection is fueled by a politics of religious difference between Hindus, Muslims, and Christians simplifies a nuanced social and political landscape in which cow-protection is inseparable from rural livelihoods, caste-based labor, dietary practices, and situated human-animal relationships (see also Govindrajan 2018; Sur 2020).

5. Two recent legal decisions reveal how successful cow-protection organizations have been in pursuing and legitimizing their political aims in Uttarakhand. In August 2018, the Uttarakhand High Court passed an order announcing that it would take on the role of parens patriae, or legal guardian, for cows across the state. Right on the heels of this decision, in September 2018, the Legislative Assembly of Uttarakhand passed a resolution declaring the cow Rashtra-Mata (national matriarch), one of the guru's key demands, and immediately forwarded it to the central government for further consideration.

6. Interestingly, even the Indian state identifies uncontrolled emotion as a primary cause of violence in the name of the cow. In 2018, the Supreme Court of India called on the central government to issue new laws aimed at preventing incidents of mob lynching. The court noted that gau-rakshaks had to "remember that they are subservient to the law and cannot be guided by ... emotions or sentiments" (Human Rights Watch 2019).

\section{REFERENCES}

Adcock, C. S.

2010 "Sacred Cows and Secular History: Cow Protection Debates in Colonial North India." Comparative Studies of South Asia, Africa and the Middle East 30, no. 2: 297311. https://doi.org/10.1215/1089201X-2010-014.

Adcock, Cassie, and Radhika Govindrajan

2019 "Bovine Politics in South Asia: Rethinking Religion, Law and Ethics." South Asia: Journal of South Asian Studies 42, no. 6: 1095-1107. https://doi.org/10.1080/0085 6401.2019.1681726.

Ahearn, Laura M.

2001 Invitations to Love: Literacy, Love Letters, and Social Change in Nepal. Ann Arbor:

Ahmed, Sara University of Michigan Press.

2003 "In the Name of Love." Borderlands e-Journal 2, no. 3.

2004 "Affective Economies." Social Text 22, no. 2 (79): 117-39. https://doi.org/10. 1215/01642472-22-2_79-117. 
2016 “Fascism as Love.” feministkilljoys, November 9, 2016. https://feministkilljoys. com/2016/11/09/fascism-as-love/.

Anderson, Edward, and Christophe Jaffrelot

2018 "Hindu Nationalism and the 'Saffronisation of the Public Sphere': An Interview with Christophe Jaffrelot." Contemporary South Asia 26, no. 4: 468-82. https://doi.

Bacchetta, Paola org/10.1080/09584935.2018.1545009.

1993 "All Our Goddesses Are Armed: Religion, Resistance, and Revenge in the Life of a Militant Hindu Nationalist Woman." Bulletin of Concerned Asian Scholars 25, no. 4:

Banaji, Shakuntala 38-52. https://doi.org/10.1080/14672715.1993.10416137.

2018 "Vigilante Publics: Orientalism, Modernity and Hindutva Fascism in India." Javnost — The Public 25, no. 4: 333-50. https://doi.org/10.1080/13183222.2018.14 63349 .

Barua, Maan

2018 “Animal Work: Metabolic, Ecological, Affective." Theorizing the Contemporary, Fieldsights, July 26. https://culanth.org/fieldsights/animal-work-metabolicecological-affective.

Bear, Laura, Karen Ho, Anna Lowenhaupt Tsing, and Sylvia Yanagisako

2015 "Gens: A Feminist Manifesto for the Study of Capitalism.” Theorizing the Contemporary, Fieldsights, March 30. https://culanth.org/fieldsights/gens-afeminist-manifesto-for-the-study-of-capitalism.

Berlant, Lauren

2011 "A Properly Political Concept of Love: Three Approaches in Ten Pages." Cultural Anthropology 26, no. 4:683-91. https://doi.org/10.1111/j.1548-1360.2011.01120.x.

Besky, Sarah, and Alex Blanchette

2018 "Introduction: The Naturalization of Work." Theorizing the Contemporary, Fieldsights,July 26.https://culanth.org/fieldsights/introduction-the-naturalizationof-work.

Chakravarti, Uma

1990 "Whatever Happened to the Vedic Dasi? Orientalism, Nationalism and a Script for the Past." In Recasting Women: Essays in Indian Colonial History, edited by Kumkum Sangari and Sudesh Vaid, 27-87. New Brunswick, N.J.: Rutgers University Press.

Chigateri, Shraddha

2011 "Negotiating the 'Sacred' Cow: Cow Slaughter and the Regulation of Difference in India." In Democracy, Religious Pluralism and the Liberal Dilemma of Accommodation,

Chowdhury, Prem edited by Monica Mookherjee, 137-59. New York: Springer.

1996 "Contours of Communalism: Religion, Caste and Identity in South-East Punjab."

Ciotti, Manuela Social Scientist 24, no. 4/6: 130-63. https://doi.org/10.2307/3517794.

2012 "Resurrecting Seva (Social Service): Dalit and Low-Caste Women Party Activists as Producers and Consumers of Political Culture and Practice in Urban North India." Journal of Asian Studies 71, no. 1: 149-70. https://doi.org/10.1017/ S002191181100297X.

Contractor, Qudsiya

2018 "Muslim Women, Caste, and the Beef Ban in Mumbai." In Gender, Caste, and the Imagination of Equality, edited by Anupama Rao, 257-73. Delhi: Women Unlimited.

Dave, Naisargi N.

2016 "Love and Other Injustices: On Indifference to Difference." Humanities Futures, Franklin Humanities Institute, Duke University. https://humanitiesfutures.org/ papers/love-and-other-injustices/. 
De, Rohit

2019 “Cows and Constitutionalism.” Modern Asian Studies 53, no. 1: 240-77. https://doi.

Dyahadroy, Swati org/10.1017/S0026749X18000422.

2009 "Exploring Gender, Hindutva, and Seva." Economic and Political Weekly 44, no. 17: 65-73. https://www.jstor.org/stable/40279187.

Eck, Diana L.

2012 India: A Sacred Geography. New York: Three Rivers.

Federici, Sylvia

1975 Wages against Housework. London: Power of Women Collective.

Freitag, Sandria B.

1980 “Sacred Symbol as Mobilizing Ideology: The North Indian Search for a 'Hindu' Community." Comparative Studies in Society and History 22, no. 4: 597-625.

Gillespie, Kathryn

2018 The Cow with Ear Tag \#1389. Chicago: University of Chicago Press.

Gold, Ann Grodzins

2006 “Love's Cup, Love's Thorn, Love's End: The Language of Prem in Ghatiyali." In Love in South Asia: A Cultural History, edited by Francesca Orsini, 303-31. Cambridge: Cambridge University Press.

Gould, William

2004 Hindu Nationalism and the Language of Politics in Late Colonial India. Cambridge: Cambridge University Press.

Govindrajan, Radhika

2018 Animal Intimacies: Interspecies Relatedness in India's Central Himalayas. Chicago: University of Chicago Press.

Forthcoming "Spectral Justice." In The Promise of Multispecies Justice, edited by Sophie Chao, Karin Bolender, and Eben Kirksey. Durham, N.C.: Duke University Press.

Gundimeda, Sambaiah

2009 "Democratisation of the Public Sphere: The Beef Stall Case in Hyderabad's Sukoon Festival." South Asia Research 29, no. 2: 127-49. https://doi.org/10.1177\% 2F026272800902900202.

Gupta, Charu

2001 "The Icon of Mother in Late Colonial North India." Economic and Political Weekly 36, no. 45: 4291-99. https://www.epw.in/journal/2001/45/special-articles/iconmother-late-colonial-north-india.html.

Gururani, Shubhra

2010 "Forests of Pleasure and Pain: Gendered Practices of Labor and Livelihood in the Forests of the Kumaon Himalayas, India." Gender, Place and Culture 9, no. 3:

Hardt, Michael 229-43. https://doi.org/10.1080/0966369022000003842.

2011 "For Love or Money." Cultural Anthropology 26, no. 4: 676-82. https://doi.org/ 10.1111/j.1548-1360.2011.01119.x.

Hoffman, Daniel

2011 "Violence, Just in Time: War and Work in Contemporary West Africa." Cultural Anthropology 26, no. 1: 34-57. https://doi.org/10.1111/j.1548-1360.2010.01079.x.

Human Rights Watch

2019 "Violent Cow Protection in India: Vigilante Groups Attack Minorities." Human Rights Watch, February 18. https://www.hrw.org/report/2019/02/18/violentImran, Mohammad cow-protection-india/vigilante-groups-attack-minorities.

2018 "Impact of 'Cow Politics' on Muslim Community: A Case Study of Ghosi Community of North India." Prabuddha: Journal of Social Equality 2, no. 1: 59-74. https://prabuddha.us/index.php/pjse/article/view/22. 
Jaffrelot, Christophe

2008 "Hindu Nationalism and the (Not So Easy) Art of Being Outraged: The Ram Setu Controversy." South Asia Multidisciplinary Academic Journal 2. https://doi.

Jalais, Annu org/10.4000/samaj.1372.

2009 Forest of Tigers: People, Politics and Environment in the Sundarbans. London: Routledge. Jegathesan, Mythri

2019 Tea and Solidarity: Tamil Women and Work in Postwar Sri Lanka. Seattle: University of Washington Press.

Johnson, Jessica

2018 Biblical Porn: Affect, Labor, and Pastor Mark Driscoll's Evangelical Empire. Durham, Joshi, Bhoomika N.C.: Duke University Press.

2018 "Regional Hindutvas: The Curious Case of Uttarakhand." Merrily, Ordinarily (blog), June 30. https://joshibhoomika.wordpress.com/2018/06/30/regionalhindutvas-the-curious-case-of-uttarakhand/.

Kaur, Raminder

2005 Performative Politics and the Cultures of Hinduism: Public Uses of Religion in Western India. London: Anthem.

Kaviraj, Sudipta

2006 “Tagore and Transformations in the Ideals of Love." In Love in South Asia: A Cultural History, edited by Francesca Orsini, 161-83. Cambridge: Cambridge University Press.

Kikon, Dolly

2019 Living with Oil and Coal: Resource Politics and Militarization in Northeast India. Seattle: University of Washington Press.

Koskimaki, Leah

2017 "Youth Futures and a Masculine Development Ethos in the Regional Story of Uttarakhand.” Journal of South Asian Development 12, no. 2: 136-54. https://doi.

Kothiyal, Tanuja org/10.1177\%2F0973174117711339.

2017 "History Teaches Us Why Today's Self-Styled Gau-rakshaks Will Harm the CattleRearing Economy.” Scroll, April 7. https://scroll.in/article/833809/history-tellsLamb, Sarah us-why-todays-self-styled-gau-rakshaks-will-harm-the-cattle-rearing-economy.

2000 White Saris and Sweet Mangoes: Aging, Gender, and Body in North India. Berkeley: University of California Press.

Mathur, Nayanika

2016 Paper Tiger: Law, Bureaucracy, and the Developmental State in Himalayan India.

Mawdsley, Emma Cambridge: Cambridge University Press.

1999 "A New Himalayan State in India: Popular Perceptions of Regionalism, Politics, and Development." Mountain Research and Development 19, no. 2: 101-12. https://

Mukherjee, Rahul doi.org/10.2307/3674251.

2020 "Mobile Witnessing on WhatsApp: Vigilante Virality and the Anatomy of Mob Lynching." South Asian Popular Culture 18, no. 1: 79-101. https://doi.org/10.1080/ 14746689.2020.1736810.

Narayan, Kirin

1992 Storytellers, Saints, and Scoundrels: Folk Narrative in Hindu Religious Teaching. Delhi: Motilal Banarsidass.

Narayanan, Yamini

2019 “'Cow Is a Mother, Mothers Can Do Anything for Their Children!' Gaushalas as Landscapes of Anthropatriarchy and Hindu Patriarchy." Hypatia 34, no. 2: 195221. https://doi.org/10.1111/hypa.12460. 
Pandey, Gyan

1986 "Rallying Round the Cow: Sectarian Strife in the Bhojpuri Region c. 18881917." In Subaltern Studies Vol. II, edited by Ranajit Guha, 60-129. Delhi: Oxford

Patel, Sujata University Press.

2010 "Seva, Sangathana, and Gurus: Service and the Making of the Hindu Nation." In Religion, Community, and Development: Changing Contours of Politics and Policy in India, edited by Gurpreet Mahajan and Surinder S. Jodhka, 102-29. New Delhi:

Paxson, Heather Routledge.

2018 "The Naturalization of Nature as Working." Theorizing the Contemporary, Fieldsights, July 26. https://culanth.org/fieldsights/the-naturalization-of-natureas-working.

Pinney, Christopher

2004 "Photos of the Gods": The Printed Image and Political Struggle in India. London: Reaktion Books.

Povinelli, Elizabeth A.

2005 "What's Love Got to Do with It? The Race of Freedom and the Drag of Descent." Social Analysis 49, no. 2: 173-82. https://doi.org/10.3167/015597705780886202.

Ramaswamy, Sumathi

2010 The Goddess and the Nation: Mapping Mother India. Durham, N.C.: Duke University Press.

Shoshan, Nitzan

2016 The Management of Hate: Nation, Affect, and the Governance of Right-Wing Extremism in Germany. Princeton, N.J.: Princeton University Press.

Stout, Noelle M.

2014 After Love: Queer Intimacy and Erotic Economies in Post-Soviet Cuba. Durham, N.C.: Duke University Press.

Sur, Malini

2020 "Time at Its Margins: Cattle Smuggling across the India-Bangladesh Border." Cultural Anthropology 35, no. 4: 546-74. https://doi.org/10.14506/ca35.4.03.

Thachil, Tariq

2014 Elite Parties, Poor Voters: How Social Services Win Votes in India. New York: Cambridge University Press.

Thomas, Deborah A.

2019a Political Life in the Wake of the Plantation: Sovereignty, Witnessing, Repair. Durham, N.C.: Duke University Press.

2019b "A Search for Repair in the Wake of the Plantation." Edge Effects, February 28. Ticktin, Miriam https://edgeeffects.net/four-days-in-west-kingston/.

2017 “A World without Innocence.” American Ethnologist 44, no. 4: 577-90. https://doi. Udupa, Sahana org/10.1111/amet.12558.

2018 "Enterprise Hindutva and Social Media in Urban India." Contemporary South Asia 26, no. 4: 453-67. https://doi.org/10.1080/09584935.2018.1545007.

van der Veer, Peter

1994 Religious Nationalism: Hindus and Muslims in India. Berkeley: University of California Press. 